\title{
The RJ Style: Brought to you by Bangladeshi FM radio
}

\author{
SABREENA AHMED \& FARHANA ZAMIL TINNY
}

\begin{abstract}
In recent years, the popularity of FM Radio stations has brought a unique change in speech style among the Bangladeshi youth. This paper compares the views of both the Radio Jockeys (RJ) and the young listeners to find out to what extent this phenomenon of RJ Speech influences the speech of the youth. The authors of the paper have selected 110 tertiary students randomly to collect their opinions through a questionnaire. Besides, seven RJs of four radio stations were interviewed and recordings of different programmes of the four FM radio stations were analysed to trace the new slang words and pronunciations used in this new style of speaking. The findings show that the young listeners think that they use this style both consciously and unconsciously. They sometimes take up this obviously "made up accent" to become a part of the popular and stylish group of friends on campus. On the other hand, the RJs do not want to admit that they are adversely influencing standard Bangla. They claim that it is up to the listeners to take the good or bad part of a programme and RJs will always adhere to their unique style.
\end{abstract}

\section{Introduction:}

FM radios have introduced a new approach to entertainment. Nowadays, we listen to traffic updates and modern Bangla and international songs on the FM radio stations while we ride our cars in the capital city. On 15 September 2006, Radio Today FM 89.6 began its journey as the first FM radio station of Bangladesh (Ishfaque, 2010). This station was much-talked about among all for bringing in the new style of speaking through the voice of RJs where they mix English accent and words in Bangla speech. Basu (2009) pointed out that any kind of code mixing between Bangla and English can be termed "Banglish", and the "anglicised" and " exaggerated" FM register "FM Banglish" (Basu, 2009, p.6). Radio Foorti 88.0 FM began its transmission on 21 September 2006, Radio Aamar 88.4 FM in February 2007 and most recently Radio ABC 89.2 FM came with the caption "jiboner notun ayojon" or "New offerings of life", in August 2008 (Ishfaque, 2010). This paper 
looks at the different perspectives of both students and radio jockeys on the debates about our standard Bangla being distorted by the RJ style of speaking.

\section{Literature Review:}

Orfella (1998) says that radio is an intimate medium that has the power to individualize its presentation in each listener's mind (p.55). It means that when someone is listening to a particular presenter on radio, his/her intimacy with that person builds on a one-to-one communication and unconsciously adopts the radio jockey's style of speech.

2.1. RJ Style: Basu (2009), in his M.A. dissertation from Institute of Education, University of London, had interviewed some listeners of FM radio stations, academicians and RJs of Bangladesh. The listener interviewees pointed out some examples of RJs' speech that helped Basu to find common characteristics of the RJs' language. He terms this language as FM Banglish and talks about the following features:

- RJs substitute the voiceless post-alveolar aspirated affricate $\left.[t]^{h}\right]$ voiceless unaspirated post alveolar fricative [S]. He uses example of the sentence, "Kemon achho, kothai jachchho."

- $\quad$ "Z" ending pluralization of words with is frequent in the speech of RJs (p. 2324). The authors of this paper noticed a similar kind of example from the gathered data in using the code-switched word "Vabs>Vabz". Bangla word "Vab" takes Englsih suffix " $z$ " instead of " $s$ " to indicate that the person who possesses "vab" or "mood" is unfriendly. It is a common coinage among the youth nowadays that is used in their peer groups.

- The RJs have a strange pitch of talk where they suddenly change their tone from low to high or vice versa to bring variation in presentation.

- RJs use an anglicized accent in the Bangla words they pronounce (Basu, 2009, p.24). 
The authors of the paper noticed two more characteristics by analyising the speech of the RJs on air:

- They use retroflex alveolar approximant [r] in Bangla with curling the tongue tip toward the palate.

- They use unnecessary nasalisation in speech.

- They pronounce Bangla aspirated oral stop [th] without any aspiration as [t].

\subsection{Code-Switching/ Code-mixing}

Gal (1979) says, "code switching is a conversational strategy used to establish, cross or destroy group boundaries to create, evoke or change interpersonal relations with their rights and obligations" (p. 247). A speaker switches from one language to another as a signal of group membership and shared belongingness with an addressee. Holmes (2001) talks about two types of code-switching that is usually found in among the speakers. One is situational code-switching which occurs because of the variety of situations of the speakers and the other one is metaphorical codeswitching that occurs because of a change of topic is needed while communication with the other speakers (p. 25). Four major forms of code-switching are identified by the scholars- tag switching (only tag part of the sentence gets switched), intra word switching (switching taking in a word), inter-sentential switching (switching between two sentences of two different languages) and intra-sentential switching (switching occurring within a sentence) (Hammink, 2000, p. 10-12).

\subsection{Taboo words}

There are certain things that cause anxiety, embarrassment or shame for people in the society and those are known as taboo. Taboo subjects vary widely ranging from the topics involving sex, death, bodily functions, religious matters, politics etc. (Wardhaugh, 2000, p.234). Every region has some taboo language and the native speakers are aware of it and they tend not to pronounce them in public. A similar avoidance has been noticed among Indian and Bangladeshi culture while using the word baal, 'hair' in Hindi and 'pubic hair' in Bangla. The word came out very 
frequently from the respondents of this research when they were asked to write about the common slang words they use. Taboo languages can also be referred as vernacular languages or non-official languages. It is the most informal register of a particular speaker (Labov, 1972, p. 283). According to him, taboo words are mostly found in adolescent peer groups in the age range of 9 to 18 years.

\subsection{Slang words:}

Slang words used by the Bangladeshi youth change frequently and it can be traced sometimes in the RJs' speech as well. College slangs mostly come in oral form, in informal settings and it is created and used primarily by students as a part of the undergraduate life. With its informal style and student orientation, college slangs have become the most expressive medium of student life which is often unknown and sometimes offensive to those who are not part of this subculture group (Hummon, 1994, p. 77).

\subsection{Social cognitive theory}

Canadian psychologist Alber Bandura's social cognitive theory has association with the way the young listeners are imitating the RJ style of speaking. Bandura (1963) through his experiment named "Bobo Doll Behavior: A Study of Aggression" showed that people actually learn from watching others. His study had the following steps involved in the modelling progression: a) Attention, b) Retention of the information, c) Reproduction in behaviour and d) Motivation to continue that behaviour in future (as cited in Boeree, 2006, p.3-4).

\subsection{Style Shift and Audience Design}

Stylization is a term related to literary and cultural criticism of Bakhtin. By stylization, Bakhtin means borrowing of the recognizable style along with any other style. It is in fact "an artistic image of another's language" and "a mixture of two social languages within the limits of a single utterance" that creates a hybrid language (as cited in Vice, 1997, p. 62). Speakers from different age groups and social class will have different styles of speaking or communicating within themselves and their choice of words, way of expression, pronunciation, 
grammatical structure differ according to many factors like-who are they talking to, what they are talking about or which place they are in on that situation (Graddol, Leith and Swann 1996, p.303). Allen Bell's theory of "audience design" (1970) is pertinent to be mentioned here as he has studied different radio newsreaders of New Zealand. Bell discovered that the tone and accent became more formal for the comparatively "educated" or "professional" audience than for the general audiences. The formality in speech was the least in case of rock music stations, popular among the young listeners (p.171). The RJs' styles of speaking change according to station's ideology because they represent those stations, e.g. ABC radio in Bangladesh tries to promote pure Bangla pronunciation and its RJs promote Bangla expressions of certain English words deliberately. Howard Giles and his associate (1970) have developed another theory on style shift named accommodation theory which suggests that, speakers will adopt the speech style of their addressee to show the unity within and avoid the style of their addressee to increase social distance (as cited in Graddol, Leith and Swann, p. 323). For example, some RJs of different radio stations adopt or shift the style of their speech into the new style that their target audience (youth) prefers most. So, it is quite clear that the RJs follow this style to make the young people feel at home and united with the radio station's programs and the RJs.

\subsection{Popular Culture}

Popular culture, commonly known as pop culture, is simply a culture which is widely accepted or well-liked by a large number of people. Popular culture includes quantitative dimension and can be studied by scrutinizing market research figures on audience preferences for different television programs, sales of any books or CD's or any style or fashion that is going on or very well welcomed by others (Storey, 2001, p.6). Orfella (1998) marks 1950s to early 1970s in the United States as the "ultimate radio era" that portrayed rock and roll legends. By the late 1980s, these music programmes moved to FM band's clearer signal and AM band introduced more talk shows and call-in shows. Both the FM and AM band radios became an inseparable part of America's popular culture in the 1990s (p.54). Similarly, in Bangladesh, 2006 was the year when FM radio started to become popular and ultimately created its own place in our country's urban culture. 


\subsection{Symbolic Power of Language}

A language often has a distinct power and prestige over other languages. Jenkins believes that the ability to speak English is considered an "added advantage or prestige" that makes everyone learn this language (Jenkins, 2009, p.41). This idea of having distinct prestige makes the RJs and their fans promote the RJ style which comprises of mixture of English and Bangla discussed previously. Bourdieu discusses the symbolic power of language which is referred as an economic exchange established to show a symbolic relation of power between a producer who speaks or follows the prestigious language and a consumer who adopts that prestigious language (Bourdieu, p. 502-503). In case of RJ style of speaking, some youngsters imitate the style and speech of the RJ's. Other young people try to follow them and speak this new language and thus the first group exerts power over the latter.

\section{Research Design:}

\subsection{Research questions:}

i. Are the youths adopting this new style consciously or unconsciously?

ii. What slang words and coinages are being used by the youths of Bangladesh nowadays? Which slang words and new words are being promoted by the RJs?

iii. To what extent does the RJ style of FM radio influence the youth to adopt this new style of speaking?

iv. Why do the young people prefer speaking in the RJ style.

v. Among the public or private university students, who are using this language more?

\subsection{The Participants}

a. Students- The research was conducted among 110 students from both public and private universities. Only 41 students were from public 
universities - Dhaka University and Eden College - and rest 69 students were from 5 private universities, namely North South University, BRAC University, American International University of Bangladesh (AIUB), Asian University, Stamford University. Students from 5 private universities participated in this research. These universities are, BRAC University (BU), North South University (NSU), American International University of Bangladesh (AIUB), Asian University and Stamford University of the capital Dhaka.

b. RJ's- Since there are only 4 FM radio stations in Bangladesh, the number of available RJ's were fewer than the students. It was possible to get interview from 7 RJs from all the 4 radio stations as it was very difficult to get time slots from them.

\subsection{The Instruments}

i. Questionnaire for tertiary students: Questionnaires were distributed among both 3 public and 5 private university students. Tertiary level students were the target students as they get more influenced than other people. The questionnaire consists of 12 multiple choice questions and 4 open-ended questions to justify their different views on different enquiries.

ii. Questionnaire for RJ's in Bangladesh: Semi-structured interviews of seven RJs from four different radio stations were taken by the authors.

iii. Recordings of the RJs' speech: A few recordings of different radio stations were analysed by the authors.

\subsection{Method of Analysis:}

Major portion of data was collected from students' responses by distributing questionnaires. Mixed method was used for collecting the data that combines both quantitative and qualitative components in the questionnaires. Interviews of the RJs were taken as well to achieve triangulation of results. Microsoft Excel was used to organize the raw data and calculate the percentages of the students' response. 


\section{Findings and Discussion:}

The following findings are taken from Farhana Zamil Tinny's M.A thesis titled "RJ Style of Speaking: Is It Creating A Sub-Culture of Bangladeshi Youth?" under the supervision of Ms. Sabreena Ahmed, at Dept. of English and Humanities, BRAC University (as cited in Tinny, 2010, p. 24-35).

\subsection{Analysis of Students' Questionnaire}

The present study is based mainly on the data collected from the tertiary level students of both public and private universities of Dhaka because FM radio stations are relayed mainly in Dhaka. 69 of the students are from private university and the rest, 41 students are from public universities. The following pie chart shows the ratio of participation of the public and private university students in this research.

\section{Ratio of public and private university students}

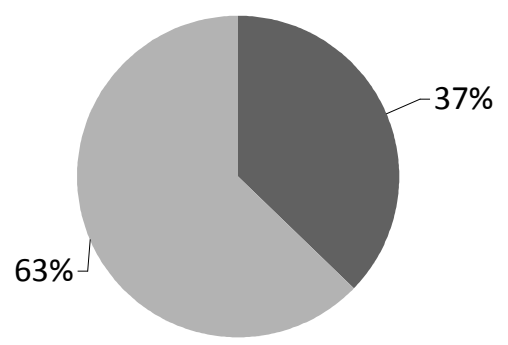

Public University

Private University

\section{Figure 1: Ratio of student participants of public and private universities}

There were 16 questions in the questionnaire that were given to the university students. The following chart shows the questions asked to the students and their responses: 


\begin{tabular}{|c|c|c|c|}
\hline Questions: & Answer Type & $\begin{array}{l}\text { Number of } \\
\text { Students }\end{array}$ & $\begin{array}{c}\text { Percentage } \\
(\%)\end{array}$ \\
\hline \multirow{3}{*}{$\begin{array}{l}\text { 1. Are you familiar with } \\
\text { the new style of and accent } \\
\text { that is usually used by our } \\
\text { youths? }\end{array}$} & Yes & 93 & 84.5 \\
\hline & No & 17 & 15.5 \\
\hline & No Comments & 0 & 0 \\
\hline \multirow{3}{*}{$\begin{array}{l}\text { 2. Do you follow this new } \\
\text { style of speaking? }\end{array}$} & Yes & 59 & 54 \\
\hline & No & 39 & 35.5 \\
\hline & No Comments & 12 & 10.5 \\
\hline \multirow{3}{*}{$\begin{array}{l}\text { 3. If you use this new style of } \\
\text { speaking, is it just because } \\
\text { you want to keep pace with } \\
\text { the trend? }\end{array}$} & Yes & 29 & 26 \\
\hline & No & 46 & 42 \\
\hline & No Comments & 35 & 32 \\
\hline \multirow{3}{*}{$\begin{array}{l}\text { 4. Do you think speaking in } \\
\text { this new style is fashionable } \\
\text { and it catches others' } \\
\text { attention easily? }\end{array}$} & Yes & 39 & 35 \\
\hline & To some extent & 25 & 23 \\
\hline & Not at all & 46 & 42 \\
\hline \multirow{3}{*}{$\begin{array}{l}\text { 5. In what way you are } \\
\text { influenced by this new style? }\end{array}$} & Unconsciously & 61 & 55 \\
\hline & Conciously & 26 & 24 \\
\hline & Not influenced & 23 & 21 \\
\hline \multirow{3}{*}{$\begin{array}{l}\text { 6. Do you think youths are } \\
\text { being influenced by the } \\
\text { new style? }\end{array}$} & Yes & 91 & 83 \\
\hline & No & 08 & 07 \\
\hline & No Comments & 11 & 10 \\
\hline \multirow{4}{*}{$\begin{array}{l}\text { 7. Do you often mix Hindi or } \\
\text { English while speaking? }\end{array}$} & Yes & 35 & 32 \\
\hline & Sometimes & 45 & 41 \\
\hline & No & 27 & 24.5 \\
\hline & No Comments & 03 & 2.5 \\
\hline \multirow{4}{*}{$\begin{array}{l}\text { 8. Where do you usually mix } \\
\text { Hindi/English in speaking? }\end{array}$} & In adda (gathering) & 60 & 55 \\
\hline & $\begin{array}{l}\text { In normal } \\
\text { conversation }\end{array}$ & 40 & 36 \\
\hline & $\begin{array}{c}\text { It happens } \\
\text { spontaneously }\end{array}$ & 06 & 05 \\
\hline & In other contexts & 04 & 04 \\
\hline 9. Do you think this can & Yes & 40 & 36 \\
\hline
\end{tabular}




\begin{tabular}{|l|c|c|c|}
\hline replace our existing standard & No & 45 & 21 \\
\cline { 2 - 4 } spoken Bangla? & No Comments & 25 & 23 \\
\hline $\begin{array}{l}\text { 10. Many people think that } \\
\text { youths who speak in this style } \\
\text { represent certain group as } \\
\text { snob, rich kids or spoilt brats. }\end{array}$ & Agree & 18 & 16 \\
\cline { 2 - 4 } Do you agree with it? & extent & 40 & 37 \\
\cline { 2 - 4 } & Disagree & 35 & 32 \\
\cline { 2 - 4 }
\end{tabular}

\section{Figure 2: Chart of students' questionnaire with responses}

- The response to the first question proves that this new style of speaking is very popular among the youth as $84.5 \%$ of the participants agreed that they were aware of this new style of speaking and only $15.5 \%$ of them said they are really not familiar with it.

- Almost half, (54\%) of the participants admitted that they prefer using this new style of speaking in their every day speech (question no.2). Around one third, $35.5 \%$ of the participants said they have not adopted this new style of speaking yet. It definitely reflects that this new style of speaking has become a part of Bangladeshi popular culture. Even though, some of the youths do not adopt this style, majority of them are familiar with it.

- Since this new style has become an 'in' fashion among young generation, question no.3 asked to find out whether they follow it to keep pace with the trend. Apparently, none of the participants agreed that they are adapting this new style of speaking just to keep pace with the trend. Only $26 \%$ of the students admitted that they are following the 'in' fashion style while speaking. But most of them, that are about $42 \%$ of the students, said that they do not follow it.

- In response to question no. 4 , around $35 \%$ of the students honestly admitted that they use this new style of speaking as because they think it is fashionable and it attracts others attention very easily while $23 \%$ have said 
that they do not adopt this style of speaking completely but only "to some extent."

- More than half of the participants (55\%) confess that they follow the new style unconsciously while $24 \%$ of them have said that they follow this new style consciously (question no. 5) as they do not want to be left out from the popular group of friends who use this style to set a trend around them. Bandura's (1963) theory on social cognition proved that human beings have a tendency to imitate any attractive, interesting and unique behaviors or actions that they are exposed to.

- Students were asked if they think the youth is being influenced by the new style of speaking (question no. 6). Usually young generation pick up some new words and use them in the middle of their conversations. $83 \%$ of the participants accepted the truth that the youths are being influenced by it enormously.

- Question no.7 and 8 were about the tendency of the youth to code switch in between Bangla, English and Hindi. More than half of the participants, $55 \%$ said that they use it in their adda or gathering with friends and a good number of the participants, $36 \%$ have said that it occurs spontaneously in their regular conversation. They not only mix codes in their friend circle but also everywhere they go. $5 \%$ participants have admitted that it happens spontaneously and they do not really remember in which places they use it.

- Many Bangladeshis think that this new style of speaking is spreading in such a way that our very own style of speaking is somehow losing its charm. So the participants were asked if they want our own standard Bangla to replace by this new style of speaking (question no. 9). Noticeably, a good number of the participants (36\%) think that new style can definitely replace our own standard of spoken language. According to them, language is changeable and no one can stop this change. Around $41 \%$ of 
the students think that this new style is like a guest appearance and cannot change our real standard of spoken Bangla anyway.

- Question 10 was asked to find out what these students think about the notion that the speakers of this new style represent certain social groups like snob, rich kids etc. Surprisingly, $16 \%$ of the participants have agreed and $37 \%$ of the participants have ticked the option 'agree to some extent' on this point of view. It seems they have a negative vibe about all those who speak in this new style.

\section{Question 11}

The next question was asked to find out the source of the new words or style used by the youths. A large number of students (45\%) picked up new words and speaking style from their friends. Around $20 \%$ of the students have said that they are getting these new words from FM Radio as it has become the most popular media to the students. Most of the FM radio studios are targeting the young people as their main listeners and they organize their programs according to their (young people) tastes. Some of the participants $(16 \%)$ have responded that they are getting it from TV as they watch multi-cultural programs because of the satellite media and they come to know about the "in" and "out" fashion in other countries, especially India and Western countries. And only $12 \%$ of the participants believe that they get this new word from other places like their neighbors, cousins, face book, yahoo or hotmail messengers etc. A bar chart is given below in Figure-3 to show the source and the percentage of where the target groups are getting their new words from. 


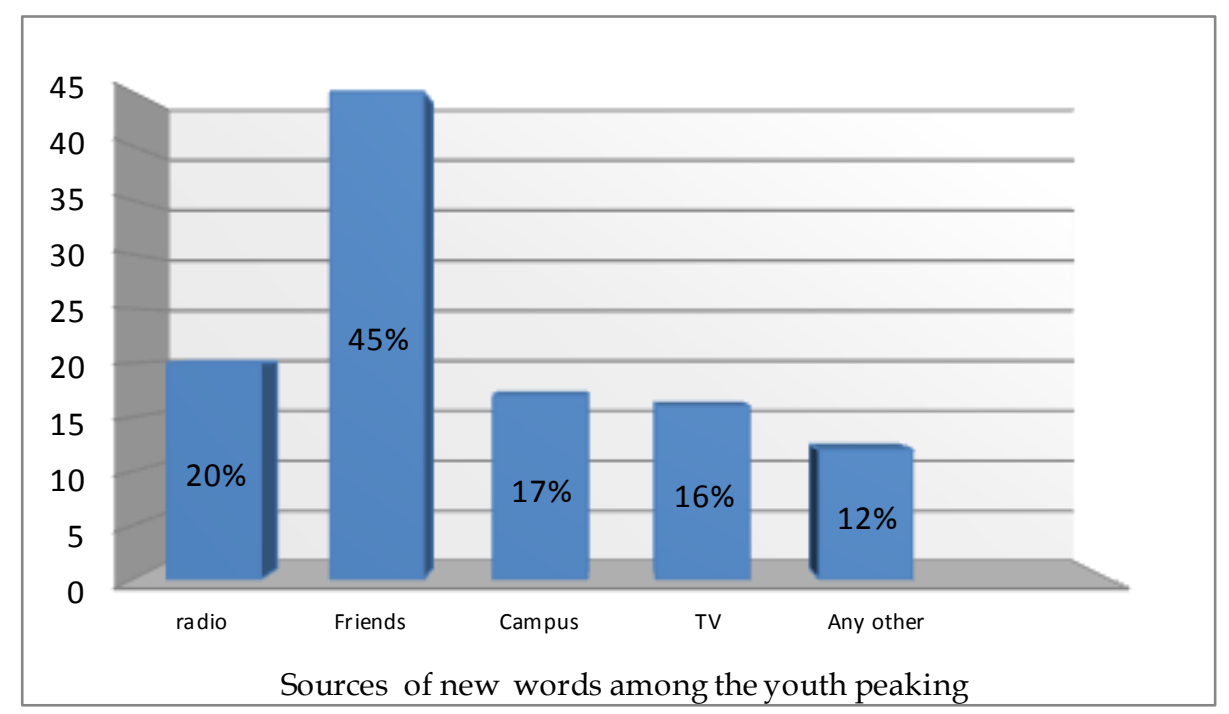

Figure 3: Source of new words in the conversation

- Comparison between the students of Private Universities and Public Universities: There is a debate that students of private universities tend to follow this new style of speaking more than the public universities. It was observed in this study that the notion is not entirely correct. Among the 110 respondents, 41 were from 3 public universities and 69 were from 5 private universities. For convenience's sake, their views have been compared on the basis of the four questions to find out to what extent RJ style influences them. The following table summarizes the findings: 


\begin{tabular}{|c|c|}
\hline $\begin{array}{l}\text { 1. Do you often mix Hindi/ } \\
\text { English while speaking? }\end{array}$ & $\begin{array}{l}\text { Public university students: } 39 \% \text { said "Yes", } 19.5 \% \\
\text { said "No", and } 39 \% \text { students said "Sometimes". } \\
\text { Private university students: } 26 \% \text { said "Yes", } 30.4 \% \\
\text { said "No", } 40.5 \% \text { said "Sometimes" and } 2.9 \% \text { said } \\
\text { "No comments." } \\
\text { Total } 78 \% \text { of Public university students and } 66 \% \\
\text { Private university students responded to the range } \\
\text { of "Yes" and "Sometimes" }\end{array}$ \\
\hline $\begin{array}{l}\text { 2. In what way you are } \\
\text { influenced by this new style? }\end{array}$ & $\begin{array}{l}\text { Public university students: } 19.5 \% \text { said that they } \\
\text { become influenced "consciously", } 51 \% \text { said that } \\
\text { they become influenced "unconsciously" and } 29 \% \\
\text { do not become influenced. } \\
\text { Private university students: } 23 \% \text { said that they } \\
\text { become influenced "consciously", } 57 \% \text { said that } \\
\text { they become influenced "unconsciously" and } 34 \% \\
\text { believe that they are not influenced at all. } \\
\text { Total } 70.5 \% \text { Public University students and } 80 \% \text { of } \\
\text { private university students admit that they are } \\
\text { influenced by this style consciously or } \\
\text { unconsciously. }\end{array}$ \\
\hline $\begin{array}{l}\text { 3. Do you think speaking in } \\
\text { this new style is fashionable } \\
\text { and catches others' attention } \\
\text { easily? }\end{array}$ & $\begin{array}{l}\text { Public university students: Majority of }(46 \%) \\
\text { students thought that the new style catches others' } \\
\text { attention, } 27 \% \text { thought it does not, and } 24 \% \\
\text { thought it does catch attention to some extent. } \\
\text { Private university students: Only } 19 \% \text { said that it } \\
\text { catches attention, } 50.72 \% \text { did not think so, and } \\
21.75 \% \text { said that it catches others' attention to }\end{array}$ \\
\hline
\end{tabular}




\begin{tabular}{|l|l|}
\hline $\begin{array}{l}\text { 4. Write some of the slang } \\
\text { Fords you usually use (e.g. } \\
\text { Fatafati, jotil, jhakkas etc.) }\end{array}$ & $\begin{array}{l}\text { Common slang words in both Public and Pvt. } \\
\text { Universities: } \\
\text { Jotil, Hebby, Fatafati, Kothin, Chorom, Jhakkas, } \\
\text { Vabs, Shala, Mama, Abar jigs, marattok, foul, } \\
\text { bapok, abbey, purai pankha, chandu, ajob/ajib, } \\
\text { baal bokchod, ajaira, bepar na, josh. } \\
\text { New slang words found in public universities: } \\
\text { Jigjag, ganjam, makkus, } \\
\text { New slang words found in private universities: } \\
\text { Nigga, Fo shizzle, Oye, thug, homie, Jomma etc. } \\
\text { were found only in private university students } \\
\text { which originated from western movies. LOL } \\
\text { (Laughing out loud), Like like like (click on the } \\
\text { "Like" button on Facebook's favourite photo, } \\
\text { comment or link) came from social network sites } \\
\text { and emails to infiltrate the spoken language. } \\
\text { "Upta dimu" is slang with a sexual connotation. } \\
\text { For details of slang words and coinages, please see } \\
\text { appendix. }\end{array}$ \\
\hline
\end{tabular}

\subsubsection{Response to open ended questions}

The following open ended questions were asked to the student participants.

a. Write some of the slang words you usually use (e.g. Fatafati, jotil, jhakkas etc.)

The slang words/new words/ taboo words that were written by the participants are listed in the table of appendix. 


\section{b. Why do you think it is important to follow any particular trend?}

In answer to this question, of the participants said that they think that it shows their smartness and it is good to change style with the current popular trend. They want to cope up with the changing environment and want show themselves as part of the other group who are following this "in-fashion" style. It is contradictory to the result of question 3 where majority of them denied that they speak in this style to keep pace with the trend. On the other hand, there is a negative perspective to this issue because total $58 \%$ of the respondents believe that speakers of this new style are snobs, rich kids or spoilt brats.

\subsection{Analysis of RJs' Interviews:}

Seven Radio Jockeys (RJs) of four 4 FM Radio stations were interviewed for this study. The RJ's will be called as RJ1, RJ2 and onwards while the authors discuss the results.

\section{Question 1}

\section{Do you mix Bangla and English randomly while speaking on air?}

In answer to this very first question all of them except for 2 RJ's from Radio $A B C$, admitted that they often code mix English and Bangla together in their speech. They said that they rarely mix Hindi while hosting their program. Some changes are getting into them so unconsciously that they are not even aware of it. For instance, the word "Ajib" (Hindi) is pronounced "Ajob" in Bangla (it means "Strange"). Interestingly, a large number of speakers in Bangladesh-mostly the young people and some of the RJs say "Ajib" instead of "Ajob". In Radio ABC, the RJ's are strictly prohibited to use or mix English with their own standard language, Bangla. For instance, RJs of radio ABC says "muthophone" instead of "cell phone", "khude barta" instead of 'SMS' and "kotha bondhu" instead of "radio jockey or RJ".

\section{Question 2}

Are you familiar with the new style of speaking and accent that is usually used by our youths (e.g. Speaking Bangla in English accent)? 
The RJs said that they know about this new style that has taken place of the Standard English and Bangla language. This language sounds as neither perfect Bangla nor perfect English but something in between. For example, nowadays, most of the young people have a tendency to mix English and Bangla together. Even sometimes they add ' $s$ ' or ' $z$ ' while addressing their peers' names like; shuvo $+z=$ shuvz or rumi $+s=$ rums etc. Six out of seven RJ's thought that students from English medium educational background are getting more influenced by this new accent or style. A reason behind this is that the English medium youngsters have a good command over English and a very poor knack for Bangla language. When they speak Bangla, they have influence of English accent. 3 of the RJs referred this new style as a distorted form of the real language but its extreme influence was seen while taking an interview of RJ 4 from Radio Today. She claimed it to be her own style.

\section{Question 3}

Do you use your natural accent/ style or any new particular style when you are on air?

Very few of the RJ's admitted that they use this new style of speaking rather than the simple style of speaking in Bangla as it attracts more audience. Some of the RJ's said that they are more concerned with being themselves and they do not follow any artificial style even if they get a bit less response from the target audience. FM radio authorities have a big contribution in adopting this new style on air as every station has its own ideologies. Some want their RJs to follow this new trend, some want them to be as natural as they are and some want them to be just a shadow of their target audience so that they can connect quickly with their target audiencemostly the young listeners.

Every individual has their own style and every organization contains some particular motto or ideologies to run their institutions. Radio Today believes in spreading information through entertainment. They have shortened this into "infotainment". On the other hand, 'Radio Aamar' encourages their RJs to be themselves and prefer accurate Bangla while communication with the audience. 
They emphasize on the accuracy of information and pronunciation very much. "Radio Foorti" wants to be more 'apon' or closer to their target audience. They want to be the friend of their target audience but not the guardian or advisor by keeping speaking style as natural as possible. Keeping a balance of both English and Bengali languages - the RJs of Radio Foorti are asked not to mix languages in between by the authority. 'Radio $A B C$ ' strictly promotes accurate Bangla while communicating their target audience and their motto is "jiboner notun ayojon" or "New offerings of life".

\section{Question 4}

\section{Do you think this accent has any special influence on your audience?}

While answering this question, every RJ's accepted this truth that new style has a great influence over the new generation. The young people like this new style of speaking and follow it as their ideal style. The RJs agreed that they are being influence by the young generation's language to some extent. They adopt the young listeners' langauge so that they can be show more unity with them on air. RJ1 of 'Radio Aamar' said that she got more SMS in response to her program when she used this new style on air. She observed this many times but she preferred accurate Bangla language while speaking to the audience or to her friends.

\section{Question 5}

\section{Do you think it is a new trend? If 'yes', then why do the young people adopt it?}

None of the RJs had any doubt actually whether it is a new trend or not. One of the RJs from 'radio abc' has blamed peer presure for young people's tendency to adopt the new style of speaking The young people do not want to be left out of the group and adopt it consciously or unconsciously. On the other hand, RJ1, from 'radio Aamar' blamed electronic media for this influence. Moreover, one of the RJ2 of "Radio Foorti" has pointed the increasing English medium educational institutes for this new trend. Students from English medium students have a common tendency to look down upon the Bangla medium students. To make them feel more inferior, they bring some kind of intonation and style in their speaking. If we 
observe this carefully, we will see that, English medium students have a tendency to act like the dominant group and at the same time, they treat Bangla medium student like 'other' or dominated group. According to RJ1, while creating this new style of speaking, the English medium students get far from the actual accent of both English and Bangla but establish it as a new trend among them. In this situation, Bangla medium students try to be like them, following this artificial style of speaking and become a part of the "wanna be group". So, he blames the "wanna be groups" but not the English medium students or Bangla medium students in general.

\section{Question 6}

\section{Are you doing this just because you want to keep pace with the trend?}

In answer to this question, no one said that they are following this new trend except RJ2 from "Radio Aamar". She explained the unconscious influence of this new style of speaking while being on air. As most of the young people are now used to this new style of speaking or switching codes between languages while talking to others, sometimes the RJ's do the same thing on air unconsciously.

\section{Question 7}

\section{Do your colleagues and producers ask you to use this style?}

None of the RJs said that they are influenced by their colleagues or producers. All of the seven RJs said that they prefer their own natural style of speaking while conducting their program on air. The competition among the radio stations and RJs, make them adopt their very own style and accents, just like a signature style. On the contrary, some of them said that, people having that extra tone and accent in their style of speaking get extra attention from the employers though the employers ask them to be as natural as possible. 'Radio today' believes in spreading information through entertainment. They have shortened this into "infotainment". On the other hand, 'Radio Aamar' encourages their RJs to be themselves and prefer accurate Bangla while communication with the audience. They emphasize on the accuracy of information and pronunciation very much. "Radio Foorti" want to be 
more 'apon' or closer to their target audience by being the friends of their target audience. The RJs of Radio Foorti are asked not to mix languages in between by the authority. And 'Radio $A B C$ ' strictly promotes accurate Bangla.

\section{Question 8}

\section{Do you think it is a good sign for our existing standard language?}

RJ1 from 'radio Aamar' thinks this new style of speaking is a huge threat to our actual mother tongue, Bangla. The rest of the RJs emphasized on using both English and Bangla language accurately. However, RJ2 from "Radio Foorti" thinks that new style of speaking has nothing to do with changing the core language. It is just a new fashion or culture that is being popular among youth for the time being. And this phenomenon is observed only in youth so it is better to say that they are creating a sub culture among themselves.

\subsection{Recordings of Radio Jockeys' speech:}

The recordings of the RJs' speech have been collected from 2008 to 2011. It has been observed that in the initial stage when FM radio was new to everyone, the RJs used to have more code-switching and anglicized accent in their speech. Around 2010, there was no RJ except for RJ4 of "Radio Today" who mixed both the languages. A reason for this is perhaps the agitated discussions and objections of the eminent linguists and senior generation of the country.

In the episode of the Good Morning Show of 'Radio Today' on 1st December 2010, RJ 4 said: "Amar sathe bindas hoye achen jara, tader bolchi..." We can see intra sentential code switching here where Hindi word "Bindas" (meaning "Free") is inserted in Bangla sentence. This RJ has promoted the word "Bepars na" (meaning: "Don't care"), on the same show which became a popular slang word among the youth in 2010.

\section{Conclusion}

It can be observed from the findings that most of the time the young generation is adopting the new style of speaking from the RJs unconsciously. Though both the 
youths and the RJs did not agree that this style of speaking can replace our standard Bangla, the young people are using this language spontaneously among themselves. They do not only blame the FM radio but overall electronic media for this change. Both the RJs and the students said that they do not follow the new style of speaking consciously, but it is true that the stylized accent grabs attention of the FM listeners quickly. The symbolic power of a unique speech style is working here which influences the audience like an invisible magician. We can encourage our young generation to learn proper Bangla and English pronunciation in educational institutes and at our homes to diminish the magic spell, but how much of this goal can be achieved is not known yet. 


\section{Works Cited}

Basu, B. L. (2009). Attitudes and resistance to language variation and change: The case of 'Banglish' on FM radio in Bangladesh. (Unpublished M.A. Dissertation). Institute of Education, University of London, UK.

Bell, A. (1991). The language of news media. Oxford: Blackwell Publishers Inc.

Boeree, G. C. (2006) Albert Bandura. Personality theories. Retrieved from http://webspace.ship.edu/cgboer/bandura.html.

Bourdieu, P. (1991). Language and symbolic power. Cambridge: Polity Press.

Coupland, N. (2001). “Dialect stylization in radio talk.” Language in society, 30 (3), 345375. Retrieved from http://www.jstor.org/.

Gal, S. (1979). Language shift: Social determinants of linguistic change in bilingual Austria. New York: Academic Press.

Graddol, D., Leith, D. and Swann, J. (1996). English: History, diversity and change (English language: Past, present and future). New York: The Open University.

Hammink, J. E. A. (2000). “Comparison of the code switching behavior and knowledge of adult and children." Retrieved from http://hamminkj.tripod.com/babel/CS_paper.htm.

Heredia, R. R. and Altarriba, J. (2001). “Bilingual language mixing: Why do bilinguals code-switch?" Current Directions in Psychological Science, 10 (5), 164-168. Retrieved from http://www.tamiu.edu/ rheredia/codeswitch.pdf.

Hockett, C. F. (1961). A course in modern linguistics. New York: Macmillan Press.

Holmes, J. (2001). An introduction to sociolinguistics. London: Longman Group.

Hummon, D. M. (1994). “College slang revisited: Language, culture, and undergraduate life." The journal of higher education, 65 (1), 75-98. Retrieved from 
http://www.jstor.org/.

Ishfaque, G. (2010, November 10). “Bangla FM radio revolution in Bangladesh.”

Shadhinota. Retrieved from http:// banglamusic.com/articles/bangla-fm-radiorevolution-in-bangladesh-1947.html.

Jenkins, J. (2009). World Englishes. 2nd ed. New York : Routledge.

Labov, W. (1990). Language and social context. Harmondsworth: Penguin Books.

Orfella, L. (1998). “Radio: The intimate medium.” The English journal, 87 (1). 53-55.

Retrieved from http://www.jstor.org/pss/822022.

Storey, J. (2001). Cultural theory and popular culture: An introduction. London: Pearson Education Limited.

Vice, S. (1997). Introducing Bakhtin. New York: Manchester University Press.

Wardhaugh, R. (2000). An introduction to sociolinguistics. Oxford: Blackwell Publishers Inc. 


\section{Appendix}

Slang words with their meanings

\begin{tabular}{|c|c|c|c|c|c|c|}
\hline Slangs & $\begin{array}{c}\text { Literal } \\
\text { meaning }\end{array}$ & $\begin{array}{c}\text { Intended } \\
\text { meaning }\end{array}$ & Origin & New words & $\begin{array}{c}\text { Code } \\
\text { Mixing }\end{array}$ & Comments \\
\hline $\begin{array}{l}\text { Jotil, } \\
\text { kothin }\end{array}$ & $\begin{array}{l}\text { Something } \\
\text { complex or } \\
\text { difficult to } \\
\text { solve }\end{array}$ & $\begin{array}{l}\text { To describe } \\
\text { the extreme } \\
\text { good of } \\
\text { anything, }\end{array}$ & Bangla & & & \\
\hline $\begin{array}{l}\text { josh, } \\
\text { chorom, } \\
\text { jhakkas }\end{array}$ & & $\begin{array}{l}\text { Again to } \\
\text { describe the } \\
\text { goodness of } \\
\text { anything }\end{array}$ & & $\begin{array}{l}\text { Jhakkas is } \\
\text { being } \\
\text { transformed } \\
\text { into } \\
\text { "jhakkus" }\end{array}$ & & \\
\hline Fatafati & $\begin{array}{l}\text { To describe } \\
\text { extreme } \\
\text { action of } \\
\text { fighting }\end{array}$ & $\begin{array}{l}\text { To say } \\
\text { something } \\
\text { beautiful or } \\
\text { wonderful }\end{array}$ & Bangla & & & \\
\hline Abar jigai & $\begin{array}{l}\text { Asking } \\
\text { something } \\
\text { again }\end{array}$ & $\begin{array}{l}\text { To ensure } \\
\text { something }\end{array}$ & Hindi & $\begin{array}{l}\text { (abar+jigai= } \\
\text { Abarjigai) } \\
\text { becomes } \\
\text { Abar Jigs } \\
\text { (with } \\
\text { English } \\
\text { suffix "S") }\end{array}$ & & \\
\hline Kahini & story & $\begin{array}{l}\text { Interesting } \\
\text { information } \\
\text { or news }\end{array}$ & Hindi & & & \\
\hline Mama & $\begin{array}{l}\text { Mothers } \\
\text { brother }\end{array}$ & $\begin{array}{l}\text { To address } \\
\text { peer group }\end{array}$ & Bangla & & & \\
\hline Shala & $\begin{array}{l}\text { Brother in } \\
\text { law }\end{array}$ & $\begin{array}{l}\text { To address } \\
\text { peer group }\end{array}$ & Bangla & & & \\
\hline $\begin{array}{l}\text { Dude, } \\
\text { buddy }\end{array}$ & Friend & $\begin{array}{l}\text { To address } \\
\text { peer group }\end{array}$ & English & & & \\
\hline $\begin{array}{l}\text { Purai } \\
\text { pangkha }\end{array}$ & $\begin{array}{l}\text { Pura means } \\
\text { "Fully", } \\
\text { Pangkha } \\
\text { means } \\
\text { "Wings" }\end{array}$ & $\begin{array}{l}\text { Someone who } \\
\text { is happy }\end{array}$ & Bangla & $\begin{array}{l}\text { Quite new } \\
\text { in use }\end{array}$ & & \\
\hline Khaise & $\begin{array}{l}\text { Associate } \\
\text { with eating }\end{array}$ & $\begin{array}{l}\text { Being } \\
\text { surprised by } \\
\text { something }\end{array}$ & Bangla & & & \\
\hline Fao & Free things & $\begin{array}{l}\text { Stupid talks } \\
\text { or thoughts }\end{array}$ & Bangla & & & $\begin{array}{l}\text { Very } \\
\text { popular } \\
\text { among } \\
\text { youth }\end{array}$ \\
\hline
\end{tabular}




\begin{tabular}{|c|c|c|c|c|c|c|}
\hline Vabs & $\begin{array}{l}\text { Being } \\
\text { moody }\end{array}$ & $\begin{array}{l}\text { Moody in } \\
\text { negative }\end{array}$ & $\begin{array}{l}\text { Bangla+E } \\
\text { nglish }\end{array}$ & $\begin{array}{l}\text { Now used } \\
\text { as "vabz" }\end{array}$ & $\begin{array}{l}\text { Vab }{ }^{+} \\
\mathrm{s} / \mathrm{z}=\mathrm{Vabs}\end{array}$ & $\begin{array}{l}\text { Over used } \\
\text { by the } \\
\text { youth }\end{array}$ \\
\hline Off ja & $\begin{array}{l}\text { To stop or } \\
\text { off }\end{array}$ & $\begin{array}{l}\text { To stop } \\
\text { someone }\end{array}$ & $\begin{array}{l}\text { English+B } \\
\text { angla }\end{array}$ & & $\begin{array}{l}\text { Off } \\
\text { (English)+ } \\
\text { ja (Bangla) }\end{array}$ & \\
\hline Ajob & Peculiar & $\begin{array}{l}\text { To explain } \\
\text { something } \\
\text { strange }\end{array}$ & Bangla & $\begin{array}{l}\text { It is used as } \\
\text { "ajib" } \\
\text { nowadays }\end{array}$ & $\begin{array}{l}\text { Switching } \\
\text { to Hindi } \\
\text { from } \\
\text { Bangla } \\
\text { word }\end{array}$ & \\
\hline $\begin{array}{l}\text { Jabardast, } \\
\text { mardanga }\end{array}$ & $\begin{array}{l}\text { Something } \\
\text { very } \\
\text { gorgeous }\end{array}$ & $\begin{array}{l}\text { Something } \\
\text { very nice }\end{array}$ & Bangla & & & $\begin{array}{l}\text { Sometimes } \\
\text { they have } \\
\text { negative } \\
\text { connotation }\end{array}$ \\
\hline Copa & $\begin{array}{l}\text { To dig } \\
\text { something }\end{array}$ & To have sex & Bangla & & & $\begin{array}{l}\text { Taboo word } \\
\text { as its } \\
\text { meaning is } \\
\text { to have sex } \\
\text { with } \\
\text { someone. } \\
\text { Young } \\
\text { people use } \\
\text { it as } \\
\text { euphemism. }\end{array}$ \\
\hline $\begin{array}{l}\text { Upta } \\
\text { dimu }\end{array}$ & $\begin{array}{l}\text { To hit } \\
\text { someone }\end{array}$ & $\begin{array}{l}\text { Sexual } \\
\text { connotation }\end{array}$ & Bangla & & & $\begin{array}{l}\text { Taboo word } \\
\text { and often } \\
\text { used as } \\
\text { euphemism } \\
\text { in group }\end{array}$ \\
\hline Bal & $\begin{array}{l}\text { Hair in } \\
\text { Hindi } \\
\text { Pubic hair } \\
\text { in Bangla } \\
\end{array}$ & $\begin{array}{l}\text { Something/s } \\
\text { ome task is } \\
\text { not } \\
\text { satisfactory }\end{array}$ & Hindi & & & $\begin{array}{l}\text { A very } \\
\text { common } \\
\text { slang }\end{array}$ \\
\hline Bokchod & $\begin{array}{l}\text { A person } \\
\text { who fails to } \\
\text { have sex } \\
\text { with girl }\end{array}$ & $\begin{array}{l}\text { Someone very } \\
\text { stupid }\end{array}$ & Bangla & & & $\begin{array}{l}\text { Taboo word } \\
\text { that means } \\
\text { a person is } \\
\text { stupid } \\
\text { (boka) and } \\
\text { he cannot } \\
\text { have sex } \\
\text { (choda) } \\
\text { properly }\end{array}$ \\
\hline Abbey & Hey you & $\begin{array}{l}\text { To call } \\
\text { someone near }\end{array}$ & Hindi & & $\begin{array}{l}\text { Sometimes } \\
\text { added } \\
\text { with } \\
\text { "Shala". } \\
\end{array}$ & \\
\hline
\end{tabular}




\begin{tabular}{|c|c|c|c|c|c|c|}
\hline & & & & & $\begin{array}{l}\text { Abbey+ } \\
\text { Shala } \\
\text { (Saley in } \\
\text { Hindi) }\end{array}$ & \\
\hline Jotil maal & $\begin{array}{l}\text { Complex } \\
\text { stuff }\end{array}$ & $\begin{array}{l}\text { To point to } \\
\text { sexy girls }\end{array}$ & $\begin{array}{l}\text { Bangla+ } \\
\text { Hindi }\end{array}$ & & $\begin{array}{l}\text { Jotil+ } \\
\text { maal }\end{array}$ & $\begin{array}{l}\text { It's a taboo } \\
\text { word used } \\
\text { to praise } \\
\text { beautiful } \\
\text { girls }\end{array}$ \\
\hline $\begin{array}{l}\text { Sucks, } \\
\text { fuck you }\end{array}$ & $\begin{array}{l}\text { Abusive } \\
\text { words }\end{array}$ & $\begin{array}{l}\text { Sexual } \\
\text { connotaion }\end{array}$ & English & & & $\begin{array}{l}\text { Often used } \\
\text { in close } \\
\text { friends' } \\
\text { group for } \\
\text { fun }\end{array}$ \\
\hline Nigga & $\begin{array}{l}\text { To point } \\
\text { out the } \\
\text { black } \\
\text { people }\end{array}$ & $\begin{array}{l}\text { To look down } \\
\text { upon } \\
\text { someone/so } \\
\text { mething }\end{array}$ & English & & & \multirow{2}{*}{$\begin{array}{l}\text { The } \\
\text { participants } \\
\text { who wrote } \\
\text { these in the } \\
\text { questionnai } \\
\text { re are from } \\
\text { private } \\
\text { university. } \\
\text { They take } \\
\text { the words } \\
\text { from } \\
\text { Hollywood } \\
\text { movies }\end{array}$} \\
\hline $\begin{array}{l}\text { Fo- } \\
\text { Shizzle, } \\
\text { Ma- } \\
\text { Nizzle, } \\
\text { G-wizz }\end{array}$ & $\begin{array}{l}\text { Was used } \\
\text { by the } \\
\text { American } \\
\text { rapstar } \\
\text { Snoop } \\
\text { Dogg in } \\
\text { some songs } \\
\text { and got } \\
\text { popularized }\end{array}$ & $\begin{array}{l}\text { To look down } \\
\text { upon } \\
\text { someone } \\
\text { / something }\end{array}$ & English & $\begin{array}{l}\text { all are } \\
\text { distorted } \\
\text { forms of the } \\
\text { English } \\
\text { slangs but } \\
\text { not originals }\end{array}$ & & \\
\hline
\end{tabular}

